\title{
Editorial
}

\section{Evil and Islamic Theodicy}

On 12 January 2010, the world witnessed the complete devastation of Haiti, this hemisphere's first black independent nation. That this is evil in its nature is disputed by none (Plato uses evil to refer to poverty, disease, pain, sickness, harm, injustice, badness, discord, chaos, disorder, ugliness, weakness, deformity, and other things). ${ }^{1}$ What is deliberated, however, are the causes, effects, and what to do next. More appropriately, the international community rallied to help the innocent and helpless Haitians instead of trying to justify why this particular earthquake occurred. In this editorial, I seek to provoke philosophical debate and refocus theological attention on evil in the world, while hoping to raise more pointed questions about those who attempted to provide absolute answers for this particular earthquake.

The very next day, the infamous televangelist Pat Robertson of the "700 Club" dared to offer an apparent justification and cause of this earthquake. ${ }^{2}$ Much has been stated about his insensitivity and the fabricated story he cited. But the absurdity of his argument and the underlying ideology are even more troubling. He concluded that God was punishing the Haitians because their ancestors had made a "pact with the Devil" to help them gain independence from France. Thus, God has cursed all generations of Haitians.

Setting aside his lack of consideration of how this pact could have been made, the underlying conclusion is that the Haitians' ancestors abandoned God in favor of the Devil (who had become effective in their quest for independence) and since then God has been taking revenge upon them, even on those citizens who follow other religions and thus have nothing to do with that alleged sin, either then or now. What does that say about God and His omnipotence and justice? Philosophers and theologians have long struggled with these questions.

Other serious questions have to do with the issue of why God chooses to punish people continuously through natural disasters or why, given His fairness, God does not punish other nations that commit the gravest forms of such sins.

There are different ways to address these questions in the context of Haiti's earthquake. What Robertson said makes no sense; however, it may be understood theologically in the context of a direct, narrow, and fanatical reading of the Bible. In sociopolitical terms it is utterly wrong, in philosophical terms it is depressingly childish, and in scientific terms it is absolutely absurd. Since my problem with his ideology lies in his theological assumption, I would rather address that directly. But first, I will briefly touch on the other ways.

Sociopolitically, Haiti could not have been cursed. While there is no sociopolitical explanation for the earthquake itself, there are many explanations for why it was 
so devastating. Haiti, a one-time French colony, had to pay massive reparations to France for its independence, ${ }^{3}$ as well as endure an American boycott, both of which quickly helped to put the country on a wrong financial and economic path. In addition to successive despotic leaders, Haiti has rarely escaped foreign interference. Internal instability forced an unreasonable migration into the capital Port-au-Prince, creating vulnerable structures and edifices. So a 7.0 earthquake stands to cause more damage in a Haiti that has been unable to prepare itself in advance. ${ }^{4}$ This explains the magnitude of the damage, but not why the earthquake took place.

Philosophically, Robertson sounds childish if not ignorant. Philosophers from Plato to Ibn Sina (Avicenna) to Thomas Aquinas have deliberated upon the problem of evil in general, including natural disasters, in an attempt to explain its existence vis-à-vis God's goodness - or lack thereof. They have also viewed it as a necessary or unreal (privation) part of existence. While these general solutions have diverse subcategories, none of them seem to insist that evil occurs as God's punishment for people's sins. ${ }^{5}$ One of the best reviews of Islam's philosophical deliberations is Shams C. Inati's The Problem of Evil: Ibn Sina's Theodicy, in which she also covers the philosophical theories of his predecessors.

Scientifically, Robertson is laughable. Earthquakes happen due to geological fault lines located all over the world, ${ }^{6}$ regardless of whether people obey God or not. To suggest that they are a result of God's curse is a complete denial of scientific reality. In fact, an earthquake's power may be minimized through a series of smaller earthquakes, and its resulting devastation may be lessened by taking various precautions in terms of where people live and how they build.

To be fair, Robertson is not the only religious person with this ideology, and therein lies our problem. Many traditional scholars of monotheistic religions make this ideological argument all the time and invoke it as a way of deterrence to their congregations. This is partly because the Bible and the Qur'an are replete with examples of narrations to that effect. In other words, God is presented as having punished some earlier peoples for their sins and still stands ready to mete out similar punishments. This editorial does not challenge the contents of those scriptures, but it does wonder about the validity of their literal interpretations and consequent application.

More importantly, it challenges the authority of those who make such judgments as to exactly what and how God does something. For instance, how does Robertson know that God is taking revenge on the Haitians, especially with the overwhelming evidence that the country is located close to one of the earthquake fault lines and thus is poised to experience earthquakes? How does he know "why" and thus conclude that God is punishing them? And finally, why would God single the Haitians out for punishment for something of which many other nations are equally guilty? Certainly the Haitians are not the worst of sinners regarding whatever one chooses to consider as sin. And, what do such ideas say about God's self-description as a just, good, and merciful being? These are fundamental problems that traditional scholars need to reconcile.

Muslim scholars have long deliberated on the problem of evil and theodicy. According to Eric Ormsby, al-Ghazali was one of the Muslim theologians who influenced the debate for centuries. Ormsby quotes him as saying "there is not in possi- 
bility anything more wonderful than what is," a statement that has been a source of dispute from the twelfth to the nineteenth century. ${ }^{7}$ The statement is relevant here not for what is says about God's power, but for what it argues about the beauty and goodness of all what is, and happens, in the world (despite all evils and shortcomings).

For his part, al-Suyuti's Kashf al-Salsalah 'an Wasf al-Zalzalah attempts to list all earthquakes known to him up until his day. But most significantly, he wanted to explain why such calamities occur. Theologically or ideologically, his answers are no different from Robertson's, except insofar as he does not blame the people of a particular nation. Ormsby writes:

In explaining earthquakes, al-Suyuti places primary emphasis on divine will. Earthquakes occur solely through divine decree ( $q a d a^{\prime}$ ). When God wishes to terrify man, He sends earthquakes. Al-Suyuti rejects explanations based on natural causes. The Philosophers are wrong to state that earthquakes occur when too many vapors (abkhirah) accumulate below ground; rather, all mountains of the earth are subterraneanly linked by "roots" ( uruq) to the legendary Mt. Qaf, the "mother of mountains...8

This supports the earlier assertion that Robertson's sentiments are traditional and not unique either to him or to the people of any particular religion. If all of this seems to single out Robertson and, to certain degree, al-Suyuti for their monotheistic ideology, things get even a bit more complicated when a local Haitian vodou (Afro-Creole religion) priest remarks that the earthquake is Mother Earth's reaction to the abuse she has endured for many years. ${ }^{9}$ Although this may be interpreted as revenge, it may also be considered as an allegorical reading of the sociopolitical and scientific explanations enunciated above.

Finally, I wish all people would just accept the fact that earthquakes are naturally scheduled events and try as much they can to minimize the effects, rather than presenting God as a jealous and unjust being seeking to revenge Himself upon poor people by randomly punishing them. AJISS would be glad to receive academic studies on the problem of evil and Islamic theodicy in their broader contexts as regards contemporary circumstances.

This issue opens with Anke Iman Bouzenita's "Islamic Legal Perspectives on Genetically Modified Food." Locating her study within a holistic context, Bouzenita considers the societal background and rationale within which GMF has been developed. She investigates the possibility of transferring certain Islamic legal devices to GMF, in regard to combining genetic material from permissible and non-permissible sources, and raises questions about using the maqasid scheme.

Imtiyaz Yusuf follows with his "The Role of the Chularajmontri (Shaykh alIslam) in Resolving Ethno-religious Conflict in Southern Thailand." Yusuf studies the crucial role of the nation's official Muslim community leader, the chularajmontri, who has been charged with resolving the conflict in Southern Thailand triggered by Siam's 1909 annexation of the former Malay sultanate of Negara Patani. He contends that the failure to do so lies in the differences between the two parties' historical, ethnic, and religious interpretation of Islam. 
The next paper, Ibrahim Olatunde Uthman's "Muslims and Science: Contributions of Islamic Universities to Professional Ethics," studies how the Islamic concept of khiläfah can be employed to revive Islamic sciences so that they can once again sustain human and other creatures. Uthman also argues that teaching secular sciences according to Islamic principles, as is being done in a few universities, will reverse some negative trends common among Muslim universities.

Lastly, M. Kabir Hassan and Muhammad Abdul Mannan Chowdhury's joint "Islamic Banking Regulations in Light of Basel II" seeks to determine if existing regulatory standards and supervisory frameworks can ensure the viability, strength, and continued expansion of Islamic financial institutions. In addition to contending that the diverse views held by the regulatory agencies of different countries on Islamic banking and finance operations make it hard to assess such banks' overall performance, they further maintain that while product diversity is important to maintaining their competitiveness, it also requires increased transparency and disclosure to improve the understanding of markets and regulatory agencies.

In conclusion, I hope that once again we have been able to assemble an excellent group of researchers to offer our readers some thought-provoking analyses with compelling conclusions.

\section{Endnotes}

1. Shams C. Inati, The Problem of Evil: Ibn Sina's Theodicy (Binghamton, NY: Global Publications, 2000), n.2, 177.

2. See www.cnn.com/2010/US/01/13/haiti.pat.robertson/index.html?iref=allsearch. For a video clip, see www.cnn.com/2010/WORLD/americas/01/14/ haiti.pat.robertson/index.html?iref=allsearch.

3. This debt, over \$21 billion in 2003 US\$ (including interest), was paid off only in 1947. See www.npr.org/templates/story/story.php?storyID=122693853.

4. See www.cnn.com/2010/OPINION/01/18/mcalister.haiti.faith/index.html?iref $=$ allsearch.

5. Inati, The Problem, 7-14.

6. See http://earthquake.usgs.gov/learn/kids/eqscience.php.

7. "Laysa fi al-imkan abda mimma kan." Eric L. Ormsby. Theodicy in Islamic Thought: The Dispute over Al-Ghazalis "Best of all Possible Worlds" (Princeton, NJ.: Princeton University Press, 1984) 32-3.

8. Ibid., 261-62.

9. See www.cnn.com/2010/OPINION/01/18/mcalister.haiti.faith/index.html? iref $=$ allsearch. 